\title{
Does the Extent of Democracy, the Degree of Income Inequality, or the Size of the Private Sector Influence National Enviromental Performance?
}

\author{
William R. DiPietro \\ Daemen College, Amherst, NY, USA \\ E-mail:wdipietr@daemen.edu
}

Received: December 13, 2012

Accepted: January 26, 2013

Online Published: March 7, 2013

doi:10.5430/rwe.v4n1p55

URL: http://dx.doi.org/10.5430/rwe.v4n1p55

\begin{abstract}
This paper uses cross country regression analysis on a newly available index that comprehensively measures total national environmental performance to look at the effect of democracy, income inequality, and the size of the private sector on national environmental performance. The evidence tends to indicate, that while democracy has a positive effect on a country's environmental performance, income inequality and the size of the private sector have a negative effect.
\end{abstract}

Keywords: Environmental performance, Private sector size, Income inequality, Democracy

\section{Introduction}

There are differences in environmental performance across countries. Some countries are more environmentally friendly than others. What accounts for this difference? Three factors, factors interesting in their own right regardless of their environmental consequences, that may possibly influence the degree of environmental conscious and the extent of environmental protection across countries are, first, differences in the amount of democracy, second, the extent of income inequality, and, third, the size of the private sector.

An often heard complaint regarding environmental research is the lack of quantitative analysis, and the limited number of observations in the quantitative research that is undertaken. Recently, a group of scholars at Yale and Columbia have undertaken the necessary tedious work to develop an index of overall environmental friendliness for a substantial number of countries around the world (Emerson and Levy et. al 2011). This brings up the promising possibility of doing quantitative research to look at the effect of differential country characteristics on the overall environment for a sizable number of countries. The purpose of this paper is to use cross country regression analysis to see whether there is any empirical evidence that three prominent country characteristics, the degree of democratic government, the amount of income inequality, and size of the private sector have an impact on the amount of expressed environmental concern of countries.

In pursuit of this objective, the paper is divided into five parts. The first part reviews some of the relevant literature. The second part puts forth and explains a simple, single equation, environmental model. The third part identifies the sources of all the variables that are used in estimating the model. The fourth section shows the results of cross country regressions of environmental performance on the extent of democracy, the amount of income inequality, and the size of the private sector. The fifth section concludes.

\section{Background Literature}

Various variables have been used in the past to explain overall environmental performance and its various components. These include, among others, population, the form of government, kind of technology employed, and income. Employing cross country regression analysis on seventy three countries of average annual percentage change in total forest area from 1990 to 2000 on a whole host of explanatory variables such as income, economic growth, population growth, democracy, domestic investment, forest stock, and world polity variables, Shandra finds support for world polity theory (Shandra 2007). Consistent with world polity theory, his regressions show that greater numbers of environmental international non-governmental organizations, higher numbers of environmental inter-governmental organizations, and more environmental treaties lead to reduced deforestation.

Shi, using pooled cross sectional regression analysis and looking at ninety three countries for the period 1975 through 1996, finds that population growth is associated with a more than proportional growth in greenhouse 
creating carbon dioxide emissions, and that the effect of population change on emissions is greater for developing countries than for developed countries (Shi 2003). In terms of the consequences of population growth on the environment, the first part of his findings tends to lend support for the Malthusian tradition over the Boscrupian tradition, while the second part of his findings for the Boscrupian tradition over the Malthusian tradition. Malthusian tradition is apprehensive of the ability of the environment to absorb waste from population growth, but the Boscrupian tradition argues that greater population pressure enhances technological innovation resulting in better solutions to environmental problems.

Fredriksson and his co-authors look at the effect of number of environmental groups, the extent of participation in elections, and the degree of political completion on the environmental performance across countries with regard to the lead content of gasoline in 1996 (Fredriksson et. al. 2003). They find that greater political competition reduces lead content, and, working through an interaction term between political competition and participation, that greater participation reduces lead emissions when there is political competition but has no effect when there is no political competition under dictatorships.

Esty and Porter maintain that for any level of economic development there is still substantial variation in environmental performance across countries, so that, other factors such as national policy, governance, quality of regulation and overall institutional make-up are apt to play a part in explaining environmental performance (Esty and Porter 2005). Using the levels of urban particulates, sulfur dioxide emissions, and energy use per unit of GDP as measures of environmental performance, empirically, they investigate whether variables in the broad areas of environmental regulation and the legal and economic arena matter for environmental performance, and find that variables in both areas are important for environmental performance.

Clausen and York look at drivers of fish biodiversity (Clausen and York 2007). Using a negative binomial regression model on cross country data with the number of threatened fish species as the dependent variable, they finds that both population size and per capita income reduce biodiversity, but that urbanization is not of consequence.

Studies trying to diagnose the effect of income on environmental often include, in addition to an income term, a squared income term in order to test for the concept known as the environmental Kuznets hypothesis. The environmental Kuznets hypothesis postulates that environmental performance initially worsens with increases in income but ultimately begins to improve with further increases in income. A survey of the literature focusing on the environmental Kuznets hypothesis can be found in Dinda (Dinda 2004). Dinda looks at both the reasons explaining the Kuznets hypothesis and at articles that test the hypothesis.

\section{The Model}

The model consists of a single equation with its associated partial derivatives. The equation is as follows.

$$
\mathrm{E}=\mathrm{f}(\mathrm{D}, \mathrm{I}, \mathrm{P}, \mathbf{C}) \quad \delta \mathrm{E} / \delta \mathrm{D}>0, \delta \mathrm{E} / \delta \mathrm{I}<0, \delta \mathrm{E} / \delta \mathrm{P}>0
$$

In the equation, $\mathrm{E}$ stands for the quality of the environment, $\mathrm{D}$ is the amount of democracy, $\mathrm{I}$ is the extent of income inequality, $\mathrm{P}$ is the size of the private sector, and $\mathbf{C}$ is a set of control variables.

The partial derivative of environmental quality on democracy is considered to be positive in the model since it is expected that greater democracy leads to greater care for the environment. Oligarchs, who focus on money making and maintaining power, are not likely to set high priority on environmental concerns. Even if the common folk in a democracy have little regard for environment matters, lobbying coupled with the free flow of information in a democracy allows special interest groups such as environmentalists to make their presence felt by those in power.

Looking at the partial derivatives of the model shows that a negative value is assigned to the partial derivative between the state of the environment and income inequality. This indicates that greater income inequality leads to reduced environmental quality. When there are high levels of income inequality, the mass of people are placing almost all of their energy and resources, doing everything they possibly can, just to earn a living. Under such circumstances, there is little available time for social concerns such as that for environmental care.

The sign of the partial derivative of environmental quality on private sector size is negative in the single equation model. The problem with the private sector, the market sector, with regard to the environment, due partially to the historical development of capitalism (as capitalism took root in a setting when environmental resources were essentially free), is that it prices its goods and services too low because it does not take into account, or does not adequately take not account, negative environmental externalities. This causes a misallocation of resources to the disadvantage of the environment. As a consequence, the bigger the private sector the greater will be the tendency of 
the economy to over allocate resources to the production of market goods and services at the expense of the environment.

Two control variables will be considered in the study. They are national happiness and the level of economic development. Both of these variables are expected to be positively related to country environmental performance.

With regard to both happiness and economic development, the essential reasoning for the positive relationship is that environmental concern, or environmental consciousness, is low in the hierarchy of priorities of human beings. Our bellies have to be filled, and we have to have adequate food, shelter, and clothing, adequate schooling and job opportunities, before environmental concerns even start to come on the radar screen. It is assumed that greater happiness and greater economic development is associated with the fulfillment of more and more of the higher items on the priority list, leading the lesser items, such as environmental issues, to begin to come into focus.

\section{The Data Sources}

The Environment Performance Index for 2010, constructed by the Yale Center for Environmental Law \& Policy and the center for International Earth Science Information Network of Columbia University, is used as the measure of environmental quality (Emerson and Levy et. al 2011). The index rates countries on a scale from zero to 100 by looking at environmental indicators in ten different categories. They include such areas as water's effect on humans, water's effect on the ecosystem, air pollution's effect on humans, air pollution's effect on the ecosystem, and climate change. For 2010, Iceland had the highest environmental performance with a score of 93.5 and Sierra Leone had the lowest with a value of 32.1 .

The Economist's Intelligence unit democracy index for 2008 (The Economist 2008) is employed to measure the extent of democracy in countries. The index scores countries from zero and ten with higher scores indicating greater democracy.

The average Gini coefficient for the years 1990 through 2007 is used to gauge income inequality. The Gini coefficient ranges from zero to a hundred with higher values indicating greater income inequality. The Gini averages are calculated directly from the annual Gini coefficient data of the World Bank (World Bank 2011). The number of years in the average Gini differs by country. Due to missing values, the average for some countries may be based on just one or two years.

The proxy used for the size of the private sector is one hundred minus the percentage of government consumption to GDP for the year 2008. The data for the percentage of government consumption to GDP for the year 2008 is taken from the World Development Indicators of the World Bank (World Bank 2010).

The measure of happiness is the average happiness of the World Data Base of Happiness for 2009 (World Data Base of Happiness 2009). Their average happiness is constructed from surveys of life satisfaction for assorted years over the years 2000 to 2009 , and varies from a low value of zero to a high value of ten.

The index of the degree of economic development is the percentage of manufacturing to GDP for the year 2005. The data for the variable comes from the World Bank.

\section{The Empirical Cross Country Results}

Table 1 shows the results of cross country regressions of environmental performance on democracy, inequality and the size of the private sector.

$<$ Insert Table 1 Here $>$

The table is arranged with the first column listing the potential explanatory variables. Each of the following columns contains the findings of an individual cross country regression equation. The equations are labeled in the first row. The last two rows show the $r$ squared values (RSQ) and the number of countries $(\mathrm{N})$. For any given equation and any independent variable entering a particular equation, the stacked two numbers in the center of the table show the estimated coefficient as the top value and the individual $t$ statistic as the bottom value in parenthesis. A single asterisk under the individual t-statistic indicates significance at the one percent level of significance or better, double asterisks at the five percent level or better and triple asterisks at the ten percent level or better.

The table contains six equations. The first three are the simple regressions of the environmental performance index on each of the three variables democracy, inequality, and the size of the private sector, separately. The fourth is the regression of environmental performance with the three variables in combination. The fifth equation adds the single control variable happiness, and the sixth equation adds both of the control variables, happiness and the level of economic development. 
The results lend support to the hypothesis that differences in the country characteristics of democracy, income inequality, and the size of the private sector are sources of differences in environmental performance between countries. The three characteristics explain close to twenty eight percent of the cross country variation in the environmental performance index when used jointly as explanatory variables (equation (4)), and explain over fifty five percent of the variation when used in combination with the two control variables (equation (6).

The estimated coefficient on democracy has its theoretically anticipated positive sign. Similarly, the estimated coefficients for income inequality and for the percentage share of the private sector to GDP are, as predicted, negative.

Democracy is significant at the one percent level of significance or better in three of the four equations in which it appears ( equations (1), (4) and (5)), and is significant at the ten percent level of significance in the remaining equation (equation (6)). The estimated coefficient for the Gini income inequality index is significant at the one percent level of significance in two of the four equations it enters (equations (2) and (5)), and significant at the five percent level or better in the other two (equations (4) and (6)). Looking at the four equations for which the size of the private sector enters as an explanatory variable, shows that the size of the private sector is significant at the one percent level in one equation (equation (3)), at the five percent level in two equations (equations (4) and (6)), and significant at the ten percent level in one equation (equation (5)).

The two control variables, happiness and the percentage of manufacturing to GDP, the measure of economic development, also work well. Happiness is positive and significant at the one percent level of significant in the two equations in which it enters (equations (5) and (6)), and the percentage of manufacturing to GDP is significant at the five percent level of significance or better in the single equation in which it appears (equation (6)).

\section{Conclusion}

The cross country regression analysis lends support to the notion that democracy, income inequality, and the size of the private sector are determinants of a country's environmental performance. Whether the variables are used singularly as explanatory variables, together in combination, or in combination when adjusting for the control variables, happiness and the level of economic development, the variables are statistically relevant.

The estimated signs on the variables in the regression analysis are pointers indicating the direction that policy needs to turn to improve environmental performance. The promotion of democracy, government measures to improve the distribution of income, such as switching from regressive to more progressive taxation, are favorable for environmental performance. Likewise, policy measures that improve the standard of living or lead to a higher level of societal happiness are also positive forces.

In demographic transition theory, excess population growth is only a short term, not a long-term problem, as countries move, make the transition, from being poor to being rich. Similarly, the lack of concern for the environment and poor environmental performance may only be a temporary, not a long term phenomenon. As countries develop, as incomes go up and people become richer and more content, as the middle class expands and inequality lessens, as the common people vie for greater democracy (as in the Arab Spring), environmental concerns will tend to come more and more into prominence. While capitalism may in the past have been a negative factor in terms of the environment because of its failure to take into consideration environmental externalities, it is the massive increase in output and income brought about by capitalism that generates conditions favorable for people to have the luxury of considering and dealing with environmental problems. The extreme environmental left, which denounces growth in the standard of living and consumption per capita as heading down the path to environmental catastrophe for the entire planet, may, if they are successful, actually be undermining future environmental support.

\section{References}

Clausen, Rebecca, \& Richard York. (2008). Global Biodiversity Decline of Marine and Freshwater Fish: A Cross-national Analysis of Economic, Demographic, and Ecological Influences. Social Science Research, 1-11.

Dinda, Soumyananda. (2004). Environmental Kuznets Curve Hypothesis: A Survey. Ecological Economics, 49, 431-455. http://dx.doi.org/10.1016/j.ecolecon.2004.02.011

Emerson, Jay, Marc A. Levy, Daniel C. Esty, Valentiana Mara, Christine Kim, Alex de Sherbinin, Tanja Srebotnjak, \& Malanding Jaiteh. (2011). Yale Center for Environmental Law and Policy (Yale University) and Center for International Earth Science Information Network (Columbia University). 2010 Environmental Performance Index, Summary for Policy [Online] Aakers. Available: http://www.ciesin.columbia.edu/repository/epi/data/2010EPI_summary.pdf (September 20, 2011) 
Esty, Daniel C., \& Michael E. Porter. (2005). National Environmental Performance: An Empirical Analysis of Policy Results and Determinants. Yale Law School Faculty Scholarship Series. Paper Number 430. [Online] Available: http://digitalcommons.law.yale.edu/fss_papers/430/(September 20, 2011)

Fredriksson, Per G., Eric Neumayer, Richard Damania, \& Scott Gates. (2005). Environmentalism, Democracy, and Pollution Control. Journal of Environmental Economics and Management, 49, 343-365. http://dx.doi.org/10.1016/j.jeem.2004.04.004

Shandra, John M. (2007). The World Polity and Deforestation A Quantitative, Cross-National Analysis. International Journal of Comparative Sociology, 48(1), 5-27. http://dx.doi.org/10.1177/0020715207072157

Shi, Anqing. (2003). The Impact of Population Pressure on Global Carbon Dioxide Emissions, 1975-1996: Evidence from Pooled Cross-Country Data. Ecological Economics, 44, 29-42. http://dx.doi.org/10.1016/S0921-8009(02)00223-9

The Economist. (2008). The Economist Intelligence Unit's democracy index. [Online] Available: http://graphics.eiu.com/PDF/Democracy\%20Index\%202008.pdf (February, 17, 2011)

World Bank. (2011). World Development Indicators. [Online] Available: http://data.worldbank.org/indicator (June 20, 2011)

World Data Base on Happiness. (2009). [Online] Available: http://worlddatabaseofhappiness.eur.nl/hap_nat/nat_fp.php (February 1, 2011)

Table 1. Cross country regressions of the environmental performance index on democracy, income inequality, and the size of the private sector

\begin{tabular}{|c|c|c|c|c|c|c|}
\hline & (1) & (2) & (3) & (4) & (5) & (6) \\
\hline CONSTANT & $\begin{array}{l}47.58 \\
(27.81) \\
*\end{array}$ & $\begin{array}{l}72.04 \\
(16.04) \\
*\end{array}$ & $\begin{array}{l}106.61 \\
(7.85) \\
*\end{array}$ & $\begin{array}{l}88.10 \\
(5.88) \\
*\end{array}$ & $\begin{array}{l}59.27 \\
(4.64) \\
*\end{array}$ & $\begin{array}{l}62.89 \\
(5.17) \\
*\end{array}$ \\
\hline DEMOCRACY & $\begin{array}{l}1.788 \\
(7.28) \\
*\end{array}$ & & & $\begin{array}{l}1.469 \\
(5.12) \\
*\end{array}$ & $\begin{array}{l}.8043 \\
(3.00) \\
*\end{array}$ & $\begin{array}{l}.4830 \\
(1.76) \\
* * *\end{array}$ \\
\hline GINI & & $\begin{array}{l}-.3287 \\
(-3.07) \\
*\end{array}$ & & $\begin{array}{l}-.2136 \\
(-2.14) \\
* *\end{array}$ & $\begin{array}{l}-.2621 \\
(-3.15) \\
*\end{array}$ & $\begin{array}{l}-.1924 \\
(-2.35) \\
* *\end{array}$ \\
\hline \multicolumn{2}{|c|}{ \%PRIVATETOGDP } & & $\begin{array}{l}-.5652 \\
(-3.52) \\
*\end{array}$ & $\begin{array}{l}.-3443 \\
(-2.09) \\
* *\end{array}$ & $\begin{array}{l}-.2490 \\
(-1.76) \\
* * *\end{array}$ & $\begin{array}{l}-.3459 \\
(-2.51) \\
* *\end{array}$ \\
\hline HAPPINESS & & & & & $\begin{array}{l}4.417 \\
(6.88) \\
*\end{array}$ & $\begin{array}{l}4.436 \\
(6.62) \\
*\end{array}$ \\
\hline \multicolumn{2}{|c|}{ \%MANFACTTOGDP } & & & & & $\begin{array}{l}.2757 \\
(2.45) \\
* *\end{array}$ \\
\hline RSQ & .255 & .065 & .076 & .278 & .525 & .554 \\
\hline $\mathrm{N}$ & 157 & 138 & 153 & 132 & 125 & 118 \\
\hline
\end{tabular}

